OPEN ACCESS

Edited by:

Giuseppe Grosso,

NNEdPro Global Centre for Nutrition and Health, United Kingdom

Reviewed by:

Justyna Godos,

Jagiellonian University, Poland

Stefano Marventano,

Ospedale Infermi di Rimini, Italy

${ }^{*}$ Correspondence:

Dipendra K. Yadav

dipendrayadavph@gmail.com

Specialty section:

This article was submitted to Clinical Nutrition

a section of the journal

Frontiers in Nutrition

Received: 21 February 2018 Accepted: 22 June 2018

Published: 16 August 2018

Citation:

Gurung LM, Bhatt LD, Karmacharya and Yadav DK (2018) Dietary Practice and Nutritional Status of Tuberculosis

Patients in Pokhara: A Cross Sectional

Study. Front. Nutr. 5:63. doi: 10.3389/fnut.2018.00063

\section{Dietary Practice and Nutritional Status of Tuberculosis Patients in Pokhara: A Cross Sectional Study}

\author{
Lal M. Gurung, Laxman D. Bhatt, Isha Karmacharya and Dipendra K. Yadav*
}

Pokhara University, School of Health and Allied Sciences, Lekhnath, Nepal

Background: Undernutrition increases the risk of progression from Tuberculosis (TB) infection to active TB disease and further leads to weight loss. Proper diet and nutrition play significant roles in treating TB patients. Active TB needs high energy requirement. The main aim of this study is to assess the dietary intake and nutritional status of TB patients in Pokhara city of Nepal.

Methods: A cross-sectional descriptive study was carried out among 133 TB patients taking anti-tubercular drug. Data were collected using sequential sampling method. Data were collected from 4th October to 7th November, 2016.

Results: This study revealed that about one-fifth of TB patients did not consume sufficient amount of calories as per RDA. More than one-third of patients were underweight during the time of registration and this is reduced to 21.8 percent in the present situation. Mean BMl was $20.99 \mathrm{~kg} / \mathrm{m}^{2}$ (SD \pm 5.81). Similarly, the mean BMl among Pulmonary TB (PTB) is 19.82 and $22.52 \mathrm{~kg} / \mathrm{m}^{2}$ in Extra PTB. Working conditions and food intake frequency were significantly associated with calorie intake. This study found that the amount of calories, food frequency per day, types of TB, and nutritional status during registration were found to be associated with recent nutritional status. The statistical difference between mean BMl at registration and recent BMl and mean weight at registration and recent weight.

Conclusion: Nutritional status has improved comparatively from the time of registration to the time of study. Proper nutritional counseling should be given to TB patients along with nutritional support to severely malnourished patients, and nutritional assessment of TB patients should be done periodically.

Keywords: tuberculosis, nutrition, diet, TB patients, Nepal

\section{INTRODUCTION}

Tuberculosis (TB) is caused by Mycobacterium tuberculosis which often affect the lungs, although it can spread to other organs in the body (1). TB is the second deadliest disease worldwide caused by a single infectious agent (1). Globally, in 2014, 9.6 million people were estimated to have fallen ill with TB; among them, 3.2 million were women, 5.4 million were men, and 1.0 million were children. Of the 9.6 million TB cases, in 2014, 12\% of them were HIV positive. Now, TB ranks along with HIV as a leading cause of death worldwide (2). However, TB is completely curable through a short course of chemotherapy (DOTS), which has been recognized as a highly cost-efficient and effective strategy (3). 
TB spreads from person to person through the air (4). There are two kinds of TB infections: latent and active. In latent TB, the bacteria remain inactive and do not show any typical signs and symptoms of TB. While they are not contagious, they can become active at any time. In active TB, the bacteria show signs and symptoms of TB and are contagious to others (1). Symptoms of active pulmonary $\mathrm{TB}$ are coughing, chest pain, fever, night

TABLE 1 | Socio-demographic characteristics of TB patients $(n=133)$.

\begin{tabular}{llcr}
\hline & Characteristics & $\boldsymbol{n}$ & $\%$ \\
\hline Age group & $10-20$ & 18 & 13.5 \\
& $20-30$ & 44 & 33.1 \\
$30-40$ & 27 & 20.3 \\
$40-50$ & 26 & 19.5 \\
& $50-60$ & 7 & 5.3 \\
& more than 60 & 11 & 8.3
\end{tabular}

Mean $=35.23$ years, $S D=15.05, \operatorname{Min}^{m}=14, \operatorname{Max}^{m}=82$

\begin{tabular}{llll}
\hline Sex & Male & 81 & 60.9 \\
Family Type & Female & 52 & 39.1 \\
& Single & 73 & 54.9 \\
Family Size & Joint & 60 & 45.1 \\
& $\leq 5$ members & 95 & 71.4 \\
& $>5$ members & 38 & 28.6 \\
\hline
\end{tabular}

Mean $=4.92, S D=2.27, \operatorname{Min}^{m}=1, \operatorname{Max}^{m}=14$

\begin{tabular}{|c|c|c|c|}
\hline \multirow[t]{4}{*}{ Marital status } & Unmarried & 45 & 33.9 \\
\hline & Married & 78 & 58.6 \\
\hline & Separated & 2 & 1.5 \\
\hline & Widow & 8 & 6.0 \\
\hline \multirow[t]{5}{*}{ Ethnicity } & Dalit Caste & 20 & 15.0 \\
\hline & Disadvantaged Janajati Caste & 21 & 15.8 \\
\hline & Disadvantaged Non Dalit Terai Caste & 3 & 2.3 \\
\hline & Advantaged Janajati Caste & 44 & 33.1 \\
\hline & Upper Caste & 45 & 33.8 \\
\hline \multirow[t]{5}{*}{ Religion } & Hindu & 115 & 86.4 \\
\hline & Buddhist & 13 & 9.8 \\
\hline & Muslim & 1 & 0.8 \\
\hline & Christian & 1 & 0.8 \\
\hline & Others & 3 & 2.2 \\
\hline \multirow[t]{7}{*}{ Occupation } & Agriculture & 37 & 27.9 \\
\hline & Employment & 25 & 18.8 \\
\hline & Household activity & 24 & 18.0 \\
\hline & Business & 16 & 12.0 \\
\hline & Student & 16 & 12.0 \\
\hline & Labor & 12 & 9.0 \\
\hline & Others(Trekking) & 3 & 2.3 \\
\hline \multirow[t]{5}{*}{ Education } & Illiterate & 15 & 11.3 \\
\hline & No-formal education & 22 & 16.5 \\
\hline & Lower secondary & 28 & 21.0 \\
\hline & Secondary & 32 & 24.1 \\
\hline & Higher secondary & 36 & 27.1 \\
\hline
\end{tabular}

sweats, weight loss, fatigue, and sometimes, the coughing up of blood (5). Active TB, like other infectious diseases, requires high energy consumption i.e., $20-30 \%$ extra energy of recommended daily allowance (RDA). Undernutrition increases the risk of progression from TB infection to an active TB disease. Food insecurity and poor nutritional status in the population are important contributors to the global burden of the TB disease (6).

Both malnutrition and TB are of considerable magnitude in most of the underdeveloped regions of the world. Nutritional status is significantly lower in patients having active TB than others (7). Therefore, the present study focused on the dietary intake and nutritional status of TB patients in Pokhara, Nepal.

TABLE 2 | Disease and health services utilization related information.

\begin{tabular}{|c|c|c|}
\hline Characteristics & $n$ & $\%$ \\
\hline \multicolumn{3}{|l|}{ Types TB $(n=133)$} \\
\hline Pulmonary TB & 73 & 54.9 \\
\hline Extra PTB & 60 & 45.1 \\
\hline \multicolumn{3}{|c|}{ Disease duration $(n=133)$} \\
\hline$<6$ months & 101 & 75.9 \\
\hline$\geq 6$ months & 32 & 24.1 \\
\hline \multicolumn{3}{|c|}{ Median $=4, I Q R=3, \operatorname{Min}^{m}=0, \operatorname{Max}^{m}=13$} \\
\hline \multicolumn{3}{|c|}{ Occurrence of complication ( $n=133)$} \\
\hline Yes & 43 & 32.3 \\
\hline No & 90 & 67.7 \\
\hline \multicolumn{3}{|c|}{ Co-morbid diseases $(n=29)$} \\
\hline Diabetes & 9 & 31 \\
\hline Arthritis & 4 & 13.9 \\
\hline Hypo-tension & 4 & 13.9 \\
\hline Kidney disease & 3 & 10.3 \\
\hline Hypertension & 2 & 6.9 \\
\hline Gastritis & 2 & 6.9 \\
\hline Thyroid & 1 & 3.4 \\
\hline HIV/AIDs & 1 & 3.4 \\
\hline Others & 3 & 10.3 \\
\hline \multicolumn{3}{|c|}{ Treatment CAT $(n=133)$} \\
\hline CAT I & 119 & 89.5 \\
\hline CAT ॥ & 14 & 10.5 \\
\hline \multicolumn{3}{|c|}{ Start to take medicine after illness $(n=133)$} \\
\hline$\leq 1$ month & 77 & 57.9 \\
\hline$>1$ month & 56 & 42.1 \\
\hline \multicolumn{3}{|c|}{ Mean $=0.97, \mathrm{SD}=1.67$} \\
\hline \multicolumn{3}{|c|}{ Phase of medication $(n=133)$} \\
\hline Intensive phase & 37 & 27.8 \\
\hline Continuous phase & 96 & 72.2 \\
\hline \multicolumn{3}{|c|}{ Duration of missing medication $(n=15)$} \\
\hline Not defaulted & 14 & 93.3 \\
\hline Defaulted & 1 & 6.7 \\
\hline
\end{tabular}


TABLE 3 | Food related information.

\begin{tabular}{|c|c|c|c|}
\hline \multicolumn{2}{|c|}{ Characteristics } & \multirow{2}{*}{$\begin{array}{l}n \\
47 \\
86\end{array}$} & \multirow{2}{*}{$\begin{array}{c}\% \\
35.3 \\
64.7\end{array}$} \\
\hline $\begin{array}{l}\text { Frequency of food } \\
\text { intake in a day }\end{array}$ & $\begin{array}{l}\leq 4 \text { times } \\
>4 \text { times }\end{array}$ & & \\
\hline$(n=133)$ & \multicolumn{3}{|c|}{ Median $=4, \mid Q R=1, \operatorname{Min}^{m}=2, \operatorname{Max}^{m}=6$} \\
\hline \multirow{2}{*}{$\begin{array}{l}\text { Meal not prepared at } \\
\text { house consumption } \\
\text { per week }(n=66)\end{array}$} & $\begin{array}{l}\leq 2 \text { days } \\
>2 \text { days }\end{array}$ & $\begin{array}{l}26 \\
40\end{array}$ & $\begin{array}{l}39.4 \\
60.6\end{array}$ \\
\hline & \multicolumn{3}{|l|}{ Median $=2, I Q R=4$} \\
\hline \multirow[t]{5}{*}{ Protein rich food ${ }^{\star}$} & Pulses & 123 & 92.5 \\
\hline & Meat & 121 & 91.0 \\
\hline & Egg & 107 & 80.4 \\
\hline & Milk and milk product & 104 & 78.2 \\
\hline & Fish & 57 & 42.9 \\
\hline \multirow[t]{2}{*}{ Protective food* } & Vegetables & 130 & 97.7 \\
\hline & Fruits & 125 & 93.9 \\
\hline $\begin{array}{l}\text { Calorie intake per day } \\
(n=133)\end{array}$ & $\begin{array}{l}\text { Not sufficient } \\
\text { Sufficient } \\
\text { Mean }=3239.39 \mathrm{Kcal} \\
\text { Max }^{\mathrm{m}}=7626.75 \mathrm{Kca}\end{array}$ & $\begin{array}{r}29 \\
104\end{array}$ & $\begin{array}{c}21.8 \\
78.2 \\
339 \mathrm{Kcal}\end{array}$ \\
\hline
\end{tabular}

*based on multiple response analysis.

\section{METHODS}

This was a cross-sectional descriptive study conducted among TB patients taking anti-tubercular drug in Pokhara, Nepal, from 4th October to 7th November, 2016. The total number of TB patients in Pokhara were 203 in FY 2072/73. The sample size was determined by assuming the prevalence of malnutrition in $\mathrm{TB}$ patients to be $51 \%$ (8), 95\% confidence limit, and 5\% marginal error, and the sample size was 133 .

List of total 12 Directly Observed Treatment Short Course (DOTS) centers in Pokhara was obtained from District Public Health Office (DPHO), Kaski, and arranged from numbers one to twelve. A sequential sampling technique was used. Of them, the required sample size was met at the 11 th DOTS center. Patients who visited the DOTS center during the data collection period were included in the study.

The structured questionnaire was developed referencing STEP wise approach to Surveillance (STEPS) survey, Nepal $(9,10)$, and was translated into the Nepali language. The questionnaire was pre-tested on $10 \%$ of the total sample in Tanahun, Nepal. Primary data collection was performed through face-to-face interviews. Tools for the data collection were a structured questionnaire, checklist (patient treatment card), bathroom scale weighing machine for weight measurement, stature meter for height measurement, and locally available cups, plates, and glasses for measuring the amount of food consumed.

Data were entered into EpiData software and analyzed by using SPSS 20 version software. Univariate and bivariate analyses were performed for data analysis. The size of dishes used to measure the amount of food was of $250 \mathrm{ml}$, which was equivalent to a standard cup size. Through this reference, the amount of food was converted into a standard serving size, and the daily energy
TABLE 4 | Nutritional Status of TB patients.

\begin{tabular}{llcc}
\hline \multicolumn{2}{c}{ Characteristics } & $\boldsymbol{n}$ & $\%$ \\
\hline Recent nutritional & Underweight & 29 & 21.8 \\
status $(n=133)$ & Normal & 81 & 60.9 \\
& Over weight & 23 & 17.3 \\
& Mean BMl $=20.99 \mathrm{k} . \mathrm{g} / \mathrm{m}^{2}, \mathrm{SD}=5.81, \mathrm{Min}^{\mathrm{m}}=13.699$ \\
& $\mathrm{~kg} / \mathrm{m}^{2}, \mathrm{Max}^{\mathrm{m}}=32.8999 \mathrm{~kg} / \mathrm{m}^{2}$ &
\end{tabular}

\section{FURTHER CLASSIFICATION OF NUTRITIONAL STATUS}

$\begin{array}{llcl}\text { Undernutrition } & \text { Severe thinness } & 6 & 20.7 \\ (n=29) & \text { Moderate thinness } & 4 & 13.8 \\ & \text { Mild thinness } & 19 & 65.5 \\ \text { Over weight } & \text { Pre-obese } & 19 & 82.6 \\ (n=23) & \text { Obese class I } & 4 & 17.4\end{array}$

\begin{tabular}{llcc}
\hline \multicolumn{2}{l}{ BASIS OF CALORIE INTAKE } & & \\
Not sufficient & Malnutrition & 9 & 31 \\
calorie intake & Normal & 13 & 44.9 \\
$(n=29)$ & Over weight & 7 & 24.1 \\
Sufficient calorie & Malnutrition & 20 & 19.2 \\
intake $(n=104)$ & Normal & 68 & 65.4 \\
& Over weight & 16 & 15.4 \\
\end{tabular}

intake was calculated by Nutrition facts 0.9 .5 .0 version and Food tables (11).

The study protocol was reviewed and approved by the Ethical Review Committee of Pokhara University Research Centre and permission was taken from DPHO Kaski. Informed verbal consent was obtained from all the participants prior to data collection, and data confidentiality was maintained.

\section{RESULTS}

Out of 133 participants, the majority $(33.1 \%)$ of them were between 20 and 30 years of age, with the mean age being 35.23 years $(S D \pm 15.05)$. More than half $(60.9 \%)$ of them were males. Most were predominantly upper caste by ethnicity and Hindu by religion (Table $\mathbf{1}$ ).

Information related to diseases and health service utilization among TB patients is given in Table 2. More than half of the patients have Pulmonary TB. 57.9\% TB patients started medication in less than 1 month after diagnosis.

Information related to food and its consumption is given in Table 3. The majority (78.2\%) of the participants consumed a sufficient amount of calories, whereas $21.8 \%$ did not. The mean was 3239.39 ( $\mathrm{SD} \pm 1352.47)$.

The nutritional status among TB patients is given in Table 4. Mean weight and height were $51.98 \mathrm{~kg}$ and $1.57 \mathrm{~m}$, respectively. Relatively, a higher percent were underweight $(21.8 \%)$ than overweight (17.3\%).

Factors which are associated with calorie intake are shown in Table 5. Working conditions and food intake frequency were significantly associated with calorie intake. Socio-demographic factors and disease-related factors were not found to be associated with calorie intake. 
TABLE 5 | Factors associated with calorie intake.

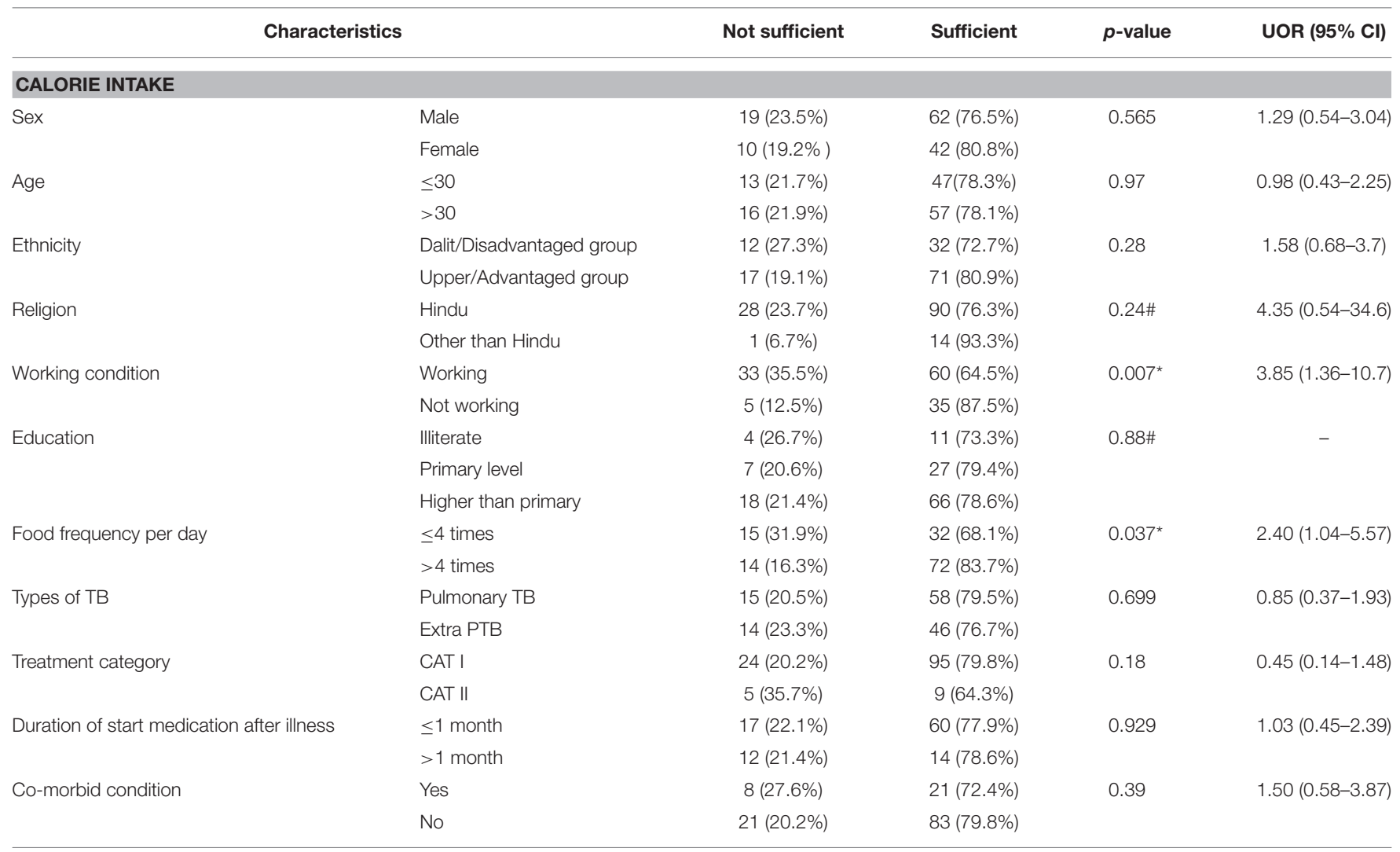

*Statistically significant p-value from bivariate analysis, \#p-value from likelihood ratio.

TABLE 6 | Factors associated with recent nutritional status.

\begin{tabular}{|c|c|c|c|c|c|}
\hline \multicolumn{2}{|c|}{ Characteristics } & Normal & Malnutrition & $p$-value & UOR (95\% Cl) \\
\hline \multicolumn{6}{|c|}{ RECENT NUTRITIONAL STATUS } \\
\hline Sex & Male & $49(60.5 \%)$ & $32(39.5 \%)$ & 0.904 & $0.96(0.46-1.95)$ \\
\hline \multirow[t]{2}{*}{ Family size } & $\leq 5$ members & $57(60.0 \%)$ & $38(40.0 \%)$ & 0.73 & $0.87(0.43-1.9)$ \\
\hline & $>5$ members & $24(63.2 \%)$ & $14(36.8 \%)$ & & \\
\hline \multirow[t]{2}{*}{ Types of TB } & Pulmonary TB & $32(43.8 \%)$ & $41(56.2 \%)$ & $0.025^{\star}$ & $0.45(0.22-0.91)$ \\
\hline & Extra PTB & $38(63.3 \%)$ & $22(36.7 \%)$ & & \\
\hline \multirow[t]{2}{*}{ Calorie intake } & Not sufficient & $13(44.8 \%)$ & $16(55.2 \%)$ & $0.045^{\star}$ & $0.43(0.186-0.992)$ \\
\hline & Sufficient & $68(65.4 \%)$ & $36(34.6 \%)$ & & \\
\hline Nutrition at registration & Normal & $61(87.1 \%)$ & $9(12.9 \%)$ & $<0.001^{\star}$ & $14.57(6.05-35.06)$ \\
\hline
\end{tabular}

*Statistically significant $p$-value from bivariate analysis.

Factors that are associated with recent nutritional status of TB patients are given in Table 6. Food frequency, TB types, calorie intake, and nutritional status at the time of registration were significantly associated with the recent nutritional status of the participants.

Statistical differences between mean BMI at registration and recent BMI (MD $-1.04 ; 95 \% \mathrm{CI}-1.05$ to $-1.39 ; p<0.001)$ and mean weight at registration and recent weight ( $\mathrm{MD}-1.52 ; 95 \%$ CI -1.004 to $-1.003 ; p<0.001$ ) are shown in Table 7 .

\section{DISCUSSION}

This study revealed that about one-fifth of TB patients did not consume sufficient amounts of calories as per the RDA. The study 
TABLE 7 | Mean difference between BMI and Weight at registration and recent $\mathrm{BMI}$ and Weight.

\begin{tabular}{lccc}
\hline & $\boldsymbol{p}$-value & Mean difference & $\mathbf{9 5 \%} \mathbf{~ C l}$ \\
\hline BMI & $<0.001^{*}$ & -1.04 & -1.05 to -1.39 \\
Weight & $<0.001^{*}$ & -1.52 & -1.004 to -1.003
\end{tabular}

${ }^{\star}$ Statistically significant $p$-value based on t-test

found that $36.1 \%$ were underweight and $11.35 \%$ were overweight during the time of registration. In contrast, studies conducted in other countries found that $51 \%$ in Ghana (8), more than $85 \%$ in India (12), $70.6 \%$ in Brazil (13), 57\% in Malawi (14), and more than $58 \%$ in Tanzania (15) were underweight during the time of registration. It might be due to the difference in sampling size and study setting. This study found that male patients were more underweight than females. In contrast, a study conducted in India found that females were more underweight than males during the time of registration (12). However, nutritional status improved by $15.3 \%$ in patients who had completed two months of medication. Other studies showed that nutritional status was improved by $11 \%$ (8) and $13.5 \%$ (12) at the end of the treatment.

The prevalence of co-morbidity was $21.85 \%$, where diabetes was the most prevalent (31\%) followed by hypotension and arthritis. A study done in Tanzania showed that prevalence of diabetes among PTB was 6.7\% (16). In India, annual cases of TB increased to $46 \%$ among people with diabetes (17).

This study found that the amount of calorie, food frequency per day, types of $\mathrm{TB}$, and nutritional status during registration was found to be associated with recent nutritional status. However, socio-demographic factors were not associated with nutritional status, whereas a study in Tanzania found that sex was significantly associated with nutritional status (18). In this study, the majority $(86.5 \%)$ of patients belonged to the Hindu religion. A study conducted in immigrant Asians from South London revealed Hindu Asians were found to have a significantly increased risk for TB compared with Muslims (19).

\section{CONCLUSIONS}

This study revealed that about one-fifth of TB patients did not consume the sufficient amount of calories as per the RDA. The Mean calorie intake was 3239.39 (SD \pm 1352.47 ). More than one-third of the patients were underweight at the time of registration, but this is reduced to $21.6 \%$ in the present situation. The mean BMI was $20.99 \mathrm{~kg} / \mathrm{m}^{2}$ (SD \pm 5.81 ): 20.56 $\mathrm{kg} / \mathrm{m}^{2}$ in males and $21.67 \mathrm{~kg} / \mathrm{m}^{2}$ in females. Similarly, mean

\section{REFERENCES}

1. McIntosh J. Tuberculosis: causes, symptoms and treatments. Medical News Today (2015).

2. WHO. Global Tuberculosis Report 2015.

3. WHO. What is DOTS (Directly Observed Chemotherapy, Short Course). SEARO (2016).

4. WHO. Tuberculosis. Geneva: World Health Organization (2015).
BMI among PTB was 19.82 and $22.52 \mathrm{~kg} / \mathrm{m}^{2}$ in Extra PTB. The prevalence of co-morbidity was $21.85 \%$, where diabetes was the most prevalent $(31 \%)$. Working conditions and food intake frequency were significantly associated with calorie intake. This study found that the amount of calories, food frequency per day, types of $\mathrm{TB}$, and nutritional status during registration were found to be associated with the recent nutritional status. There was statistical differences between mean BMI at registration and after treatment and mean weight at registration and after treatment. It was increased after treatment. The nutritional status has improved comparatively from the time of registration to the present situation. Proper nutritional counseling along with nutritional support should be given to severely malnourished TB patients, and nutritional assessment of TB patients should be done periodically.

\section{ETHICS STATEMENT}

Ethical clearance was obtained from the institutional review committee of Pokhara University at the beginning of the study. Detailed information was available in Nepali to all participants. Confidentiality was maintained and the information was used for research purposes only. Each participants participated voluntarily in this study. Written consent was taken from all the participants before the data collection. Participants were informed about their BMI status. In case of an abnormal range, educational counseling was given regarding a balanced diet and they were referred to a nutritionist for the further services.

\section{AUTHOR CONTRIBUTIONS}

LG was the principle investigator for the study. She compiled all contributor tasks, generated the topic and reviewed the related literature. LG and LB facilitated data collection. DY designed the study methodology and overall analysis and helped write the results section. LG, LB, and IK drafted the manuscript. DY reviewed the manuscript.

\section{FUNDING}

DY received a Faculty Research Grant from the University Grant Commission of Nepal and the research was titled Prevalence of Diabetes Mellitus among TB Patients and their Quality of Life in Western Region of Nepal in 2016 (Nepalese fiscal year 20722073). DY was required to supervise the dissertation of students researching in a similar area.

5. Sinclair D, Abba K, Grobler L, Sudarsanam TD. Nutritional supplements for people being treated for active tuberculosis. Cochrane Database Syst Rev. (2011) 9:CD006086. doi: 10.1002/14651858.CD006086

6. WHO. Guideline: Nutritional Care and Support for Patients With Tuberculosis. Geneva: World Health Organization (2013).

7. Gupta KB, Gupta R, Atreja A, Verma M, Vishvkarma S. Tuberculosis and nutrition. Lung India (2009) 26:9. doi: 10.4103/0970-2113. 45198 
8. Dodor E. Evaluation of nutritional status of new tuberculosis patients at the effia-nkwanta regional hospital. Ghana Med. J. (2008) 42:22-28.

9. Kumar Aryal K, Neupane S, Mehata S, Vaidya A, Singh S, Paulin F, et al. Non Communicable Diseases Risk Factors: STEPS Survey Nepal 2013. (2013).

10. Lamsal A. Assessment of Food Intake by Children Attending Montessori School of Pokhara Valley Faculty of Health Science. Lekhnath: Pokhara University (2015).

11. Park K. Park's Textbook of Preventive and Social Medicine, 19th Edn. Jabalpur: Banarsidas Bhanot Publishers (2007).

12. Bhargava A, Chatterjee M, Jain Y, Chatterjee B, Kataria A, Bhargava M, et al. Nutritional status of adult patients with pulmonary tuberculosis in rural central India and its association with mortality. PLoS ONE (2013) 8:e77979. doi: 10.1371/journal.pone.0077979

13. Bacelo AC, Ramalho A, Brasil PE, Cople-Rodrigues Cdos S, Georg I, Paiva E, et al. Nutritional supplementation is a necessary complement to dietary counseling among tuberculosis and tuberculosis-HIV patients. PLoS ONE (2015) 10:e0134785. doi: 10.1371/journal.pone. 0134785

14. Zachariah R, Spielmann M, Harries A, Salaniponi F. Moderate to severe malnutrition in patients with tuberculosis is a risk factor associated with early death. Trans $R$ Soc Trop Med Hyg. (2002) 96:291-4.

15. Kennedy N, Ramsay A, Uiso L, Gutmann J, Ngowi F, Gillespie S. Nutritional status and weight gain in patients with pulmonary tuberculosis in Tanzania. Trans R Soc Trop Med Hyg. (1996) 90:162-6.
16. Mugusi F, Swai A, Alberti K, McLarty D. Increased prevalence of diabetes mellitus in patients with pulmonary tuberculosis in Tanzania. Tubercle (1990) 71:271-6.

17. Dye C, Bourdin Trunz B, Lonnroth K, Roglic G, Williams BG. Nutrition, diabetes and tuberculosis in the epidemiological transition. PLoS ONE (2011) 6:e21161. doi: 10.1371/journal.pone.0021161

18. PrayGod G, Range N, Faurholt-Jepsen D, Jeremiah K, Faurholt-Jepsen M, Aabye MG, et al. Sex, smoking, and socioeconomic status are associated with body composition among tuberculosis patients in a deuterium dilution cross-sectional study in Mwanza, Tanzania. J Nutr. (2013) 143:735-41. doi: $10.3945 /$ jn. 112.168997

19. Strachan DP, Powell KJ, Thaker A, Millard FJ, Maxwell JD. Vegetarian diet as a risk factor for tuberculosis in immigrant south London Asians. Thorax (1995) 50:175-80.

Conflict of Interest Statement: The authors declare that the research was conducted in the absence of any commercial or financial relationships that could be construed as a potential conflict of interest.

Copyright (c) 2018 Gurung, Bhatt, Karmacharya and Yadav. This is an open-access article distributed under the terms of the Creative Commons Attribution License (CC $B Y)$. The use, distribution or reproduction in other forums is permitted, provided the original author(s) and the copyright owner(s) are credited and that the original publication in this journal is cited, in accordance with accepted academic practice. No use, distribution or reproduction is permitted which does not comply with these terms. 